\title{
Wilms Tumor 1 Gene Syndromes
}

National Cancer Institute

\section{Source}

National Cancer Institute. Wilms Tumor 1 Gene Syndromes. NCI Thesaurus. Code C131006.

A group of syndromes caused by autosomal dominant mutation(s) in the WT1 gene, encoding Wilms tumor protein. 